\title{
Heavy Metal Contamination and Ecological Risk Assessment of Overlying Water and Sediments of Nkozoa Lake (Southern Cameroon)
}

\author{
Noa Tang Sylvie Désirée ${ }^{1^{*}}$, Ekoa Bessa Armel Zacharie ${ }^{2}$, \\ Tchakam Kamtchueng Brice ${ }^{3}$, Wongan Kouonchie Sorel Ange ${ }^{2}$, \\ Etame Jacques ${ }^{4}$ and Bilong Paul ${ }^{2}$ \\ ${ }^{1}$ Department of Biological Sciences, Higher Teacher Training School, University of Yaoundé I, \\ Cameroon. \\ ${ }^{2}$ Department of Earth Sciences, Faculty of Science, University of Yaoundé I, Cameroon. \\ ${ }^{3}$ Hydrological Research Centre, Institute of Geological and Mining Research (IRGM), Box 4110, \\ Yaoundé, Cameroon. \\ ${ }^{4}$ Department of Earth Sciences, University of Douala, P.O.Box 24157, Douala, Cameroon.
}

\section{Authors' contributions}

This work was carried out in collaboration among all authors. Authors NTSD and EBAZ designed the study, performed the statistical analysis, wrote the protocol and wrote the first draft of the manuscript. Authors TKB and WKSA managed the analyses of the study. Authors EJ and BP managed the literature searches. All authors read and approved the final manuscript.

Article Information

DOI: 10.9734/ARRB/2021/v36i430366 Editor(s):

(1) Prof. Ibrahim Farah, Jackson State University, USA. Reviewers:

(1) Muhammad Sajid Mehmood, Northwest University, China. (2) Che-Jung Hsu, National Taiwan University, Taiwan. Complete Peer review History: http://www.sdiarticle4.com/review-history/67858

Original Research Article

Received 22 February 2021 Accepted 28 April 2021 Published 01 May 2021

\begin{abstract}
Examination of heavy metals ( $\mathrm{Cr}, \mathrm{Cu}, \mathrm{Zn}, \mathrm{Pb}, \mathrm{Hg}, \mathrm{Cd}$ and $\mathrm{Ni}$ ) in overlying water and sediments was conducted in Lake Nkozoa, in a peripheral area of Yaoundé characterized by a high population density and rapid economic development in Cameroon. Sediment samples were collected at the entrance and near the center of the lake, using a raft and polyvinyl chloride (PVC) pipes. They were subjected to water quality parameters, heavy metals comparisons and calculations of pollution indices and ecological risks followed by statistical analysis in order to identify and estimate the sources of metal contamination in overlying water and sediments of the Nkozoa Lake. The
\end{abstract}


physico-chemical parameters of water show that the $\mathrm{pH}(5<\mathrm{pH}<6)$, total dissolved solids (TDS 130 $\mathrm{g} / \mathrm{L})$ and conductivity $(\mathrm{EC} \sim 194.8 \mu \mathrm{s} / \mathrm{cm})$ are below the recommendations of the WHO. The average heavy metal concentrations in sediments, except $\mathrm{Cd}$, are lower than the upper continental crust (UCC) and several environmental contamination monitoring parameters, such as threshold effect level (TEL), probable effect level (PEL), and severe effect level (SEL). The sediment samples show a low heavy metal contamination degree (class 0 ) and low potential ecological risk (PER) level, except for $\mathrm{Cd}$ and $\mathrm{Hg}$ which have high contamination degree (class 1 to 6) and moderate PER. Matrix correlation shows that some parameters like $\mathrm{pH}, \mathrm{EC}, \mathrm{Cr}$ and TDS, $\mathrm{Cu}, \mathrm{Hg}$ in water have perfect positive correlations $(r=1.00)$ suggesting common sources of contamination. Cluster analyses coupled with matrix data for sediments revealed that $\mathrm{Cd}$ is the most contaminant elements derived from anthropogenic sources.

Keywords: Nkozoa lake; overlying water; sediments; heavy metals; contamination; ecological risk.

\section{INTRODUCTION}

Environmental pollution by heavy metals has been a hotly debated topic over the last two decades. The issue of heavy metal pollution in sediments and in the water of lakes and rivers has received much more attention from many environmental researchers. As a result of industrial development and the increasing use of its by-products, every day a large amount of industrial waste is dumped into low-lying areas and water bodies as lakes without adequate treatment. It is assumed that the balance between metals in sediments and freshwater is disturbed [1-4], and would contribute to increase water contamination which can produce health effects [2].

Generally, sediments provide useful information on the state of environmental and even geochemical pollution [5,6]. Depending on environmental conditions and hydrodynamic features, metallic trace elements, especially heavy metals, tend to adsorb from the water column onto the surfaces of fine particles and generally move with the sediment, and can affect benthic, pelagic and even planktonic organisms and, to some extent, the food chain if toxic levels are reached, thus posing a health risk [7-9].

According to Filgueiras et al. [10], less than 1\% of pollutants are dissolved in water while more than $99 \%$ are stored in sediments throughout the hydrological cycle. Consequently, sediment represents one of the ultimate sinks for heavy metals released into the aquatic environment $[11,12]$. But, heavy metals, presented here as contaminants, are not necessarily bound to sediment, but may also be released into the water column through various remobilization processes. Thus, in water bodies, sediment can be both a vector and a potential source of pollutants $[13,14]$. Lake water is used as household and irrigation water for agriculture and fish farming. It is also important in maintaining soil fertility, transportation, development of forest resources and wildlife conservation [5]. However, most of the lakes in urban areas of developing and underdeveloped countries are at the end of their lifespan and also places of accumulation of pollutants due to industrial and domestic effluents that are discharged into them [15-18]. There is therefore a need for a water quality monitoring program for rivers and lakes in highly urbanized areas to protect human health and preserve water resources [19,20].

Through the aim of creating employment opportunities, eradicating poverty, and promoting rapid economic growth, the Government of Cameroon has decided to put in place a development policy that aims to improve the living conditions of its people by 2035. Due to a very cheap local labour force and somewhat relaxed environmental and tariff regulations, foreign and local investors are strongly attracted to create manufacturing units for exportable products including textiles, dyeing, plastics, metal fabrication, semiconductor products, foam tanning and so on. Every day, huge amounts of metals from industries are discharged without proper treatment into watersheds and lakes. A case in point is the Nkozoa artificial Lake located at the entrance of Yaoundé (capital of Cameroon). Effluents generated by industries, dwellings upstream of Lake Nkozoa are discharged into its watershed and then carried into the lake, causing great concern for the aquatic environment. In addition, local farmers frequently use water from the Nkozoa Lake and rivers, supplying this lake for irrigation and fishing. However, no detailed study has been carried out so far in this area, in particular on the ecological risk assessment of heavy metal contamination. Therefore, the purpose of this study is to investigate the physico-chemical properties (i.e., pH, TDS (total dissolved solids) 
and electrical conductivity (EC)) of water, as well as the contents of heavy metals $(\mathrm{Cr}, \mathrm{Cu}, \mathrm{Zn}, \mathrm{Pb}$, $\mathrm{Hg}, \mathrm{Cd}$ and $\mathrm{Ni}$ ) in sediment and water from the Nkozoa Lake, to generate the water quality and the metal distributions and concentrations in the studied lake on the one hand, and to assess the degree of contamination and potential ecological risk in the study area on the other hand. It is important to understand the status of heavy metal contamination in Lake Nkozoa in order to provide a baseline for waste control and management for local authorities and residents.

\section{MATERIALS AND METHODS}

\subsection{Study Area}

The area of investigation for this study is an artificial lake created three decades ago. Lake Nkozoa, as it is known, is located at the northern entrance of Yaoundé, the political capital of Cameroon (Fig. 1a). It is situated between latitudes $3^{\circ} 57^{\prime} 41^{\prime \prime}$ and $3^{\circ} 57^{\prime} 57^{\prime \prime} \mathrm{N}$ and longitudes $11^{\circ} 32^{\prime} 09^{\prime \prime}$ and $11^{\circ} 32^{\prime} 32^{\prime \prime}$ (Fig. 1b). The area is rich in industrial establishments such as textiles, dyeing and clothing. Upstream of this lake, agriculture is strongly practiced. Effluent from these structures is discharged into the shallows that flow into the lake. During the dry season, agricultural, household and industrial effluents are deposited on the crests of watersheds and river banks, while during the rainy season, the land overflows and the toxic constituents of the effluents are washed away from nearby villages and other water bodies including the river that feeds Nkozoa Lake (Fig.1c).

The study area is characterized by a four-season equatorial climate ( 2 rainy and 2 dried seasons); with a cumulative annual precipitation of 1498 $\mathrm{mm}$ and an average annual temperature of $24^{\circ} \mathrm{C}$. The vegetation is typical of the GuineanCongolese type with Atlantic forest Biafran to Caesalpiniaceae. The South Cameroonian plateau is the geomorphological unit to which the study area belongs. It has an average altitude of $700 \mathrm{~m}$ where the upper altitudes are made up of high peaks reaching up to $1200 \mathrm{~m}$ and the lowlands drained by the watercourses of the Foulou sub-catchment area. These climatic and geomorphological conditions are at the origin of the formation of ferralitic soils on the interfluves and hydromorphic soils in the marshy lowlands.

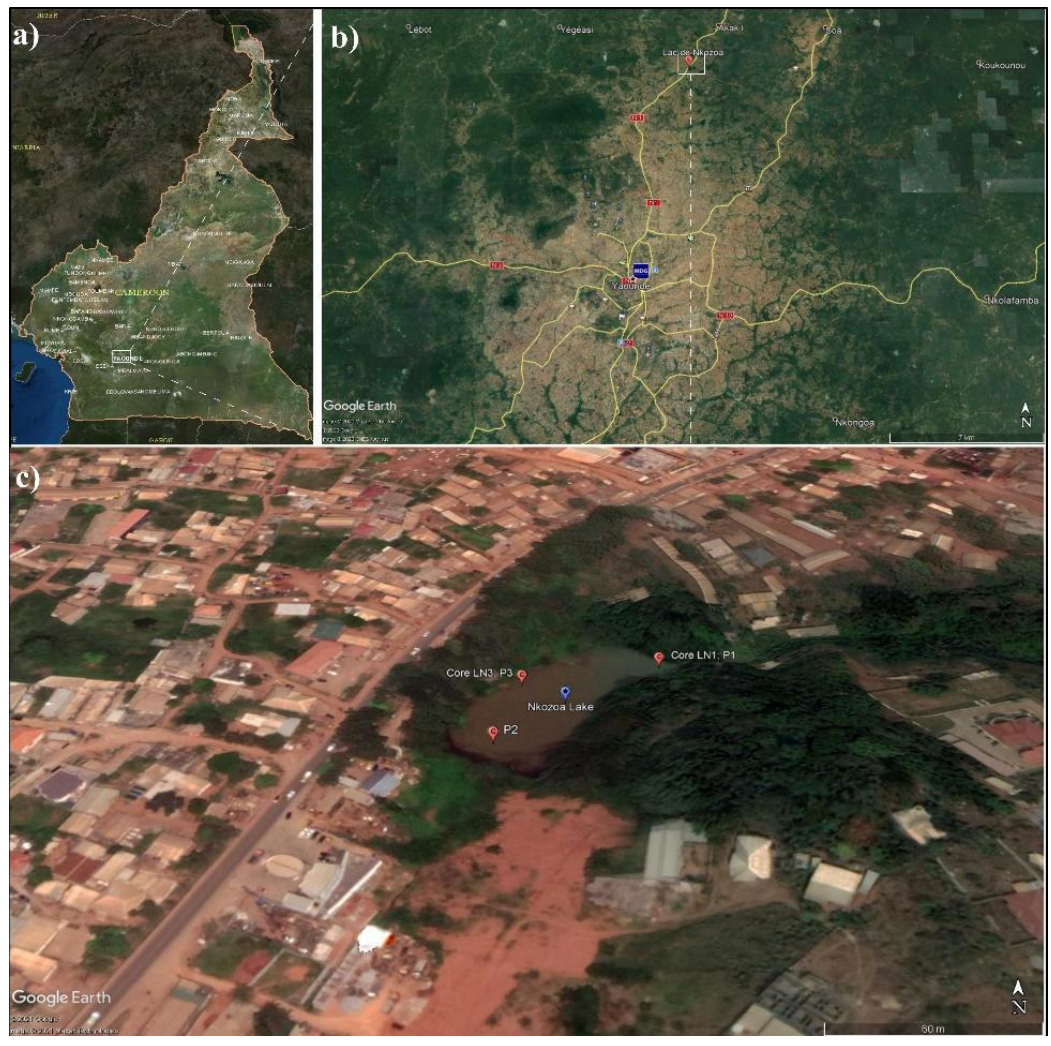

Fig. 1. Investigated area and sampling location: a) location of the study area in Cameroon; b) location of Nkozoa Lake in Yaoundé and c) sampling location of water and sediments 
Geologically, the study area is located in the Yaoundé Group whose lithological nature is essentially composed of granulite, migmatite and schists. These rocks are organized into two main lithological entities more or less migmatized: (a) a meta-bearing unit consisting essentially of pyriclasites, pyroxenites and talcschists (b) a metasedimentary unit consisting essentially of garnet and kyanite gneiss, garnet and plagioclase gneiss and garnet micaschists in which are intercalated levels of calcium silicate rocks and in places quartzites and talcschists [21]. The study area is located in this metasedimentary unit.

\subsection{Sampling}

Two sediment cores (LN and LA) were collected using PVC pipes in a wood raft inside the Nkozoa Lake. The sampling procedure is similar to that described by many authors [e.g., 22,23]. For each of the two cores selected for this study, sampling was done every $10 \mathrm{~cm}$. Thus, seven samples were taken from the core LN (LN1 to LN7) located near the entrance of the lake and six samples from the core LA (LA1 to LA6) taken near the center of the lake. The thirteen sediment samples taken from the cores were air dried and then dried again in an oven at $40^{\circ} \mathrm{C}$ for 24 hours at the Laboratory of Geosciences of Superficial Formations and Applications (GSFA) of the University of Yaoundé I (Cameroon) before being crushed in a Fritsch electric pulverizer. The resulting powders $(\theta<80 \mu \mathrm{m})$ were submitted to heavy metal analysis at the Laboratories of the Botswana International University of Sciences and Technology (BIUST) in Botswana.

Water samples from Nkozoa Lake were collected at three predetermined locations (at the entrance, middle and outlet of the lake; Fig. 1b) during the short rainy season. Water samples were collected in pre-cleaned plastic bottles following filtering through Whatman filter paper No. 541 and stored in a $4^{\circ} \mathrm{C}$ refrigerator with the addition of $2 \mathrm{mg} / \mathrm{l} \mathrm{HNO} 3$ prior to laboratory analysis [24].

\subsection{Analytical Procedures}

A quantity of $1 \mathrm{~g}$ of each dried sediment sample was taken from a clean Pyrex test tube and digested with $1 \mathrm{ml}$ of $\mathrm{HClO}_{4}$ diluted to $70 \%, 4 \mathrm{ml}$ of $\mathrm{HNO}_{3}$ concentration at $150^{\circ} \mathrm{C}$ in an oil bath. The solution was diluted with deionized water and quantitatively filtered (Whatman No. 541) into a $50 \mathrm{ml}$ volumetric flask. A blank and a standard reference material were digested in the same way for quality control and accuracy verification. The determination of heavy metals $(\mathrm{Cr}, \mathrm{Cu}, \mathrm{Zn}, \mathrm{Pb}, \mathrm{Hg}, \mathrm{Cd}$ and $\mathrm{Ni}$ ) in all sediment samples was performed by an Agilent 4200 Microwave Plasma-Atomic Emission Spectrometer (MPAES) at BIUST. All samples were collected and analysed in triplicate and the average results were used to represent the data. The statistical software, xlstat 20.0 and Microsoft Excel 2016, were used for hierarchical cluster analysis, and for a correlation matrix of heavy metals in water and sediment.

Measurements were made for physico-chemical parameters for water samples in the field, including $\mathrm{pH}$, electrical conductivity (EC), and total dissolved solids (TDS), using the HI 9811-5 portable $\mathrm{pH}$ meter, which was calibrated before and during the campaign. Alkalinity was determined using a Hach field titration kit within 8 $\mathrm{h}$ after sample collection, in which a volume of $0.16 \mathrm{NH}_{2} \mathrm{SO}_{4}$ was added dropwise to the sample while continuously stirring with a $\mathrm{pH}$ meter to reach the final titration ( $\mathrm{pH} \square$ 4.5). The method for sampling water in this lake is described in detail by Mimba et al. [25]. All samples were collected in new 50-ml polyethylene bottles, previously washed, rinsed separately with distilled and collected water. Trace element (Cr, $\mathrm{Cu}, \mathrm{Zn}, \mathrm{Pb}, \mathrm{Hg}, \mathrm{Cd}$ and $\mathrm{Ni}$ ) concentrations were determined in water samples by inductively coupled plasma mass spectrometry (ICP-MS) with certified reference materials $(\mathrm{JA}-3, \mathrm{JB}-3$, JG-3) and blanks were simultaneously analyzed to check for analytical precision and accuracy in Japan Geological Survey, Japan. The detection limit varies between 0.01 and 3 ppm.

\subsection{Assessment of Contamination}

\subsubsection{Geo-accumulation index (Igeo)}

An essential criterion for assessing the intensity of metal pollution is the geo-accumulation index [26]. This empirical index compares a given concentration against a value considered as geochemical background.

$$
\text { Igeo }=\log 2(\mathrm{Cn} / 1.5 \mathrm{Bn})
$$

Where Igeo = geo-accumulation index; log2 = logarithm to base $2 ; \mathrm{n}=$ element of interest; $\mathrm{C}=$ measured sample concentration; $\mathrm{B}=$ geochemical background; $1.5=$ geochemical background exaggeration factor, which is designed to account for natural fluctuations in 
geochemical background. In addition, Muller [26] defined a scale of values with six classes depending on the intensity of the pollution. This scale stipulates that: Igeo < 0 (class 0 ), no contamination; 0-1 (1), no to slight contamination; 1-2 (2), moderate contamination; 2-3 (3), moderate to heavy contamination; 3-4 (4), heavy contamination; 4-5 (5), heavy to extreme contamination and Igeo $>5$ (6) indicates extreme contamination.

\subsubsection{Contamination Factor Pollution Load Index (PLI)}

(CF) and

The Contamination Factor (CF) was used to express the level of contamination by each metal in the sediment. It is expressed as:

$$
\mathrm{CF}=\left(\frac{\mathrm{C}_{\text {metal }}}{\mathrm{C}_{\text {background }}}\right)
$$

Where Cmetal is the concentration of the element in the sediment sample and Cbackground is the geochemical background value of the element by Taylor and McLennan [27]. Due to the absence of geochemical background for Yaoundé sediments continental crustal values of Taylor and McLennan [27] were considered as representative of the geochemical background. CF values were interpreted as suggested by Hakanson [28], where: CF $<1$ indicates low contamination; $1 \leq \mathrm{CF}<3$ is moderate contamination; $3 \leq \mathrm{CF}<6$ is significant contamination; and $\mathrm{CF}>6$ is very high contamination. The assessment of the degree of contamination was also carried out using the Pollution Load Index (PLI). The latter has been widely used to assess the level of contamination and pollution in lake sediments. A PLI value greater than 1 indicates progressive deterioration of sediment quality [29]. The equation used to calculate PLI was developed by Tomlinson et al. [29].

$$
\text { PLI }=\sqrt[n]{(\mathrm{CF} 1 \times \mathrm{CF} 2 \times \mathrm{CF} 3 \times \ldots \ldots \times \mathrm{CFn}}
$$

Where CF is the contamination factor, and $n$ the number of elements analyzed. The relationships between the elements analyzed were tested on the basis of the Pearson's coefficient with a statistical significance set at $p<0.05$.

\subsection{Ecological Risk Assessment}

The ecological risk assessment was conducted for the potential ecological risk (PER) such as potential ecological risk index (RI) and potential ecological risk factor (Er). The potential ecological risk index (RI) for heavy metals is known as the sum of the risk factors and was developed for six toxic metals using the equations of Hakanson [28] and Zhu et al. [30].

$$
\mathrm{RI}=\sum_{1}^{\mathrm{n}} \mathrm{Er} \text { and } \mathrm{Er}=\mathrm{Tr} \times \mathrm{CF}
$$

where $\mathrm{Er}$ is the unique index of the ecological risk factor, and $\mathrm{n}$ is the quantity of the heavy metal class, $\mathrm{Tr}=$ toxic response factor suggested by Hakanson [28] for seven metals: $\mathrm{Cr}$ (5), Cd (30), $\mathrm{Cu}$ (5), Pb (5), Ni (5), Zn (1) and $\mathrm{Hg}$ (40). The $\mathrm{Er}$ and $\mathrm{RI}$ express the potential ecological risk factor for each metal and for several metals, respectively. The following expressions were used for the potential ecological risk factor: $\mathrm{Er}<$ 40, low potential ecological risk; $40 \leq \mathrm{Er}<80$, moderate potential ecological risk; $80 \leq \mathrm{Er}<160$, significant potential ecological risk; $160 \leq \mathrm{Er}<$ 320 , high potential ecological risk; and $\mathrm{Er} \geq 320$, very high ecological risk. In addition, the potential ecological risk index is: $\mathrm{RI}<150$, low ecological risk; $150 \leq \mathrm{RI}<300$, moderate ecological risk; $300 \leq \mathrm{RI}<600$, significant ecological risk; and RI $>600$, very high ecological risk [28].

\section{RESULTS AND DISCUSSION}

The results presented and discussed in this study take into account the physico-chemical parameters, variations and the degree of contamination by heavy metals $(\mathrm{Cr}, \mathrm{Cu}, \mathrm{Zn}, \mathrm{Pb}$, $\mathrm{Hg}, \mathrm{Cd}$ and $\mathrm{Ni}$ ) in water and sediment samples taken from Lake Nkozoa in Yaoundé, Cameroon.

\subsection{Assessment of Contamination}

The physico-chemical parameters including $\mathrm{pH}$, EC and TDS of Lake Nkozoa are presented in Table 1. The values found reveal that the $\mathrm{pH}$ is acidic at all three sampling points in Lake Nkozoa $(5<\mathrm{pH}<6$; Fig. 2). This would be due, on the one hand, to the alteration of silicic rocks such as quartzites and gneiss found in the Yaoundé zone and also to the weak hydrolysis leading to the formation of illite in this area [16], and on the other hand, the presence of garages, households and hairdressing salons around the lake and its sub-basin by the dumping of products such as vehicle batteries, wicks for hairdressing, toxic products and household waste. The $\mathrm{pH}$ (between 6.5 and 8.5) is below the recommendations of the World Health Organization (WHO). It is also lower than those found in Bini and Dang Lakes in northern Cameroon [31], and those in the municipal lake of Yaoundé at around $15 \mathrm{~km}$ of Lake Nkozoa [32; 
Table 1]. The acid values of the water of this lake are lower than those of a healthy lake ( $\mathrm{pH}$ 6.5), which could cause significant changes in the planktonic community such as the appearance of mosses and less useful planktonic species and the progressive loss of certain species like certain fish, fry, tadpoles are likely.

Conductivity measurement is a good assessment of the degree of contamination of water where each ion acts by its specific concentration and conductivity. The recorded values show small variations. They fluctuate between $190.4 \mu \mathrm{s} / \mathrm{cm}$ at P1 and $198.3 \mu \mathrm{s} / \mathrm{cm}$ at P3 (Fig. 2; Table 1) in the waters of Lake Nkozoa indicating leaching of the surrounding metamorphic rocks and runoff of domestic and semi-industrial residues.

The salinity of the water at our sampling points ranges from $124 \mathrm{~g} / \mathrm{L}$ measured at the lake entrance to $145 \mathrm{~g} / \mathrm{L}$ reported towards the centre of the lake. The TDS value is $124 \mathrm{~g} / \mathrm{L}$ at the outlet of the lake (Fig. 2; Table 1). This situation of high salinity of the water is not exclusively related to the wastewater discharges from the locality of Nkozoa but also to the geological nature of the land crossed by the lake's watershed.

\subsection{Heavy Metal Contents}

\subsubsection{Heavy metals in water}

The heavy metal concentrations in the waters of Lake Nkozoa are shown in Table 1. It appears that the values (in $\mathrm{mg} / \mathrm{L}$ ) of heavy metals in these waters vary as follows: $\mathrm{Cu}(\sim 5.463)>\mathrm{Ni}(\sim$ 1.470 $)>\mathrm{Hg}(\sim 0.492)>\mathrm{Cr}(\sim 0.346)>\mathrm{Cd}(\sim$ $0.047)>\mathrm{Pb}(\sim 0.018)>\mathrm{Zn}(\sim 0.006)$. On the one hand, concentrations of all metals, except $\mathrm{Zn}$ and $\mathrm{Cr}$, are above the WHO recommended values (3 $\mathrm{mg} / \mathrm{L}$ and $0.05 \mathrm{mg} / \mathrm{L}$ respectively) for drinking water [33]. On the other hand, low concentrations of $\mathrm{Zn}(0.006 \mathrm{mg} / \mathrm{L})$ and $\mathrm{Cr}(0.346)$ were observed in all sampling points, exceeding the environmental quality standard in $100 \%$ of the points. On the whole, these values are slightly higher than those found in several lakes around the world, including Lake Tuskegee in the USA [34]; Lake Nokoue in Benin [35]; Lakes Bini and Dang in North Cameroon [31] and in the municipal lake of Yaoundé near Lake Nkozoa [32]. This difference between the data for Lake Nkozoa and the other lakes (Table 1) could be related to the proximity of small trades and mostly households near the lake. These results indicate that contamination in metals, except $\mathrm{Zn}$, has become a major environmental problem in and around Lake Nkozoa. The main source of heavy metals in the waters of the lake under investigation is the discharge of waste streams from various industrial processes, such as metallurgical alloys, ceramics, metal plating, photography, pigment mills, and textile printing and hair treatment industries [5]. Agriculture and farming carried out in the watershed of Lake Nkozoa may also contribute to increasing the concentration of metals in the lake water. These features show that water of Lake Nkozoa are of poor quality for domestic use and aquatic life according to the above-mentioned standards.

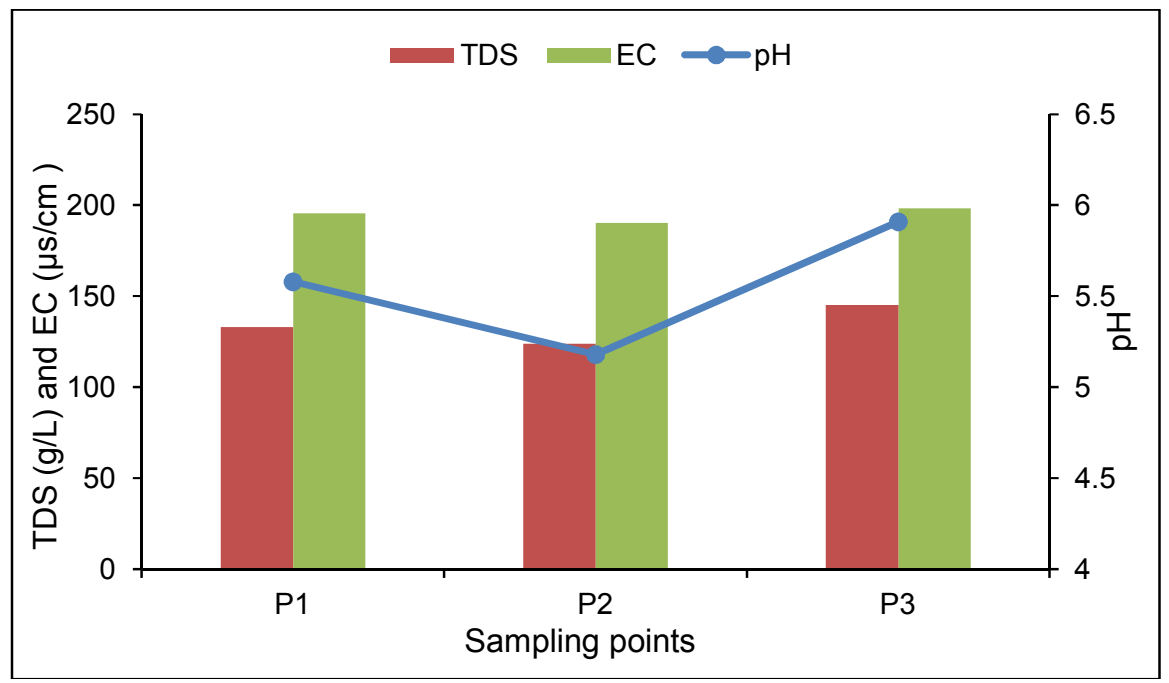

Fig. 2. Variations in the contents of physico-chemical parameters 
Noa Tang et al.; ARRB, 36(4): 92-109, 2021; Article no.ARRB. 67858

Table 1. Heavy metal concentrations, physicochemical parameters of Nkozoa Lake water samples $(\mathrm{mg} / \mathrm{L})$ and comparison with values taken from other lakes around the world

\begin{tabular}{|c|c|c|c|c|c|c|c|c|c|c|}
\hline & $\mathrm{pH}$ & TDS & EC & $\mathrm{Cr}$ & $\mathrm{Cu}$ & $\mathrm{Zn}$ & $\mathbf{P b}$ & $\mathrm{Hg}$ & $\mathbf{C d}$ & $\mathbf{N i}$ \\
\hline P1 & 5.58 & 133 & 195.6 & 0.356 & 5.264 & 0.018 & 0.041 & 0.430 & 0.009 & 1.468 \\
\hline P2 & 5.18 & 124 & 190.4 & 0.313 & 4.954 & 0.004 & 0.029 & 0.303 & 0.029 & 1.683 \\
\hline P3 & 5.91 & 145 & 198.3 & 0.378 & 5.972 & 0.008 & 0.007 & 0.681 & 0.064 & 1.257 \\
\hline Mean Nkoazoa Lake (present study) & 5.56 & 134.00 & 194.77 & 0.35 & 5.40 & 0.01 & 0.03 & 0.47 & 0.03 & 1.47 \\
\hline WHO [33] & - & - & - & 2 & 0.05 & 3 & 0.01 & 0.006 & 0.003 & 0.07 \\
\hline Tuskegee Lake, USA [34] & 7.24 & - & 185.2 & 0.0021 & 0.0012 & 0.0057 & 0.0007 & - & 0.00001 & 0.0066 \\
\hline Nokoue Lake, Benin [35] & - & - & - & - & 0.2 & - & 0.08 & - & $<0.01$ & - \\
\hline Municipal Lake, Cameroon [32] & 7.22 & - & 304 & - & 0.008 & 0.012 & 0.016 & - & 0.007 & 0.006 \\
\hline Bini Lake, Cameroon [31] & 7.74 & - & - & 0.00001 & - & 0.00001 & 0.00002 & - & 0.00003 & 0.00001 \\
\hline Dang Lake, Cameroon [31] & 7.6 & - & - & 0.00002 & - & 0.00004 & 0.00002 & - & 0.00004 & 0.00002 \\
\hline
\end{tabular}


Table 2. Heavy metal concentrations $(\mathrm{mg} / \mathrm{kg})$ in Nkozoa Lake sediment samples

\begin{tabular}{llllllll}
\hline & $\mathbf{C r}$ & $\mathbf{C u}$ & $\mathbf{Z n}$ & $\mathbf{P b}$ & $\mathbf{H g}$ & $\mathbf{C d}$ & $\mathbf{N i}$ \\
\hline LN1-1 & 4.219 & 3.483 & 0.456 & 0.444 & 4.395 & 0.211 & 0.317 \\
LN1-2 & 0.256 & 0.255 & 0.146 & 0.060 & 0.24 & 0.31 & 0.078 \\
LN1-3 & 0.501 & 0.220 & 0.217 & 0.100 & 0.592 & 0.197 & 0.084 \\
LN1-4 & 0.362 & 0.119 & 0.144 & 0.074 & 0.369 & 0.195 & 0.066 \\
LN1-5 & 0.708 & 0.341 & 0.303 & 0.130 & 0.744 & 0.163 & 0.122 \\
LN1-6 & 0.856 & 0.296 & 0.327 & 0.133 & 1.311 & 0.186 & 0.099 \\
LN3-1 & 0.267 & 0.356 & 0.142 & 0.088 & 0.172 & 0.193 & 0.140 \\
LN3-2 & 0.687 & 0.439 & 0.380 & 0.159 & 0.776 & 0.318 & 0.100 \\
LN3-3 & 0.440 & 0.325 & 0.366 & 0.141 & 0.726 & 0.245 & 0.126 \\
LN3-4 & 0.881 & 0.289 & 0.238 & 0.215 & 0.724 & 0.256 & 0.074 \\
LN3-5 & 0.738 & 0.230 & 0.351 & 0.252 & 3.33 & 0.145 & 0.111 \\
LN3-6 & 1.042 & 0.331 & 0.505 & 0.392 & 2.366 & 0.154 & 0.147 \\
LN3-7 & 0.53 & 0.170 & 0.225 & 0.326 & 3.132 & 9.384 & 0.088 \\
Min. & 0.256 & 0.119 & 0.142 & 0.060 & 0.172 & 0.145 & 0.066 \\
Max. & 4.219 & 3.483 & 0.505 & 0.444 & 4.395 & 9.384 & 0.317 \\
Avg. & 0.884 & 0.527 & 0.292 & 0.193 & 1.452 & 0.920 & 0.119 \\
\hline \multicolumn{7}{c}{ Guidelines for metals contamination in sediment } \\
\hline TEL & 37.3 & 35.7 & 123 & 35 & 0.174 & 0.596 & 18 \\
PEL & 70 & 197 & 315 & 91.3 & 0.486 & 3.53 & 36 \\
SEL & 110 & 110 & 820 & 250 & 2 & 10 & 75 \\
\hline \multicolumn{7}{c}{ MacDonald et al. (2000) }
\end{tabular}

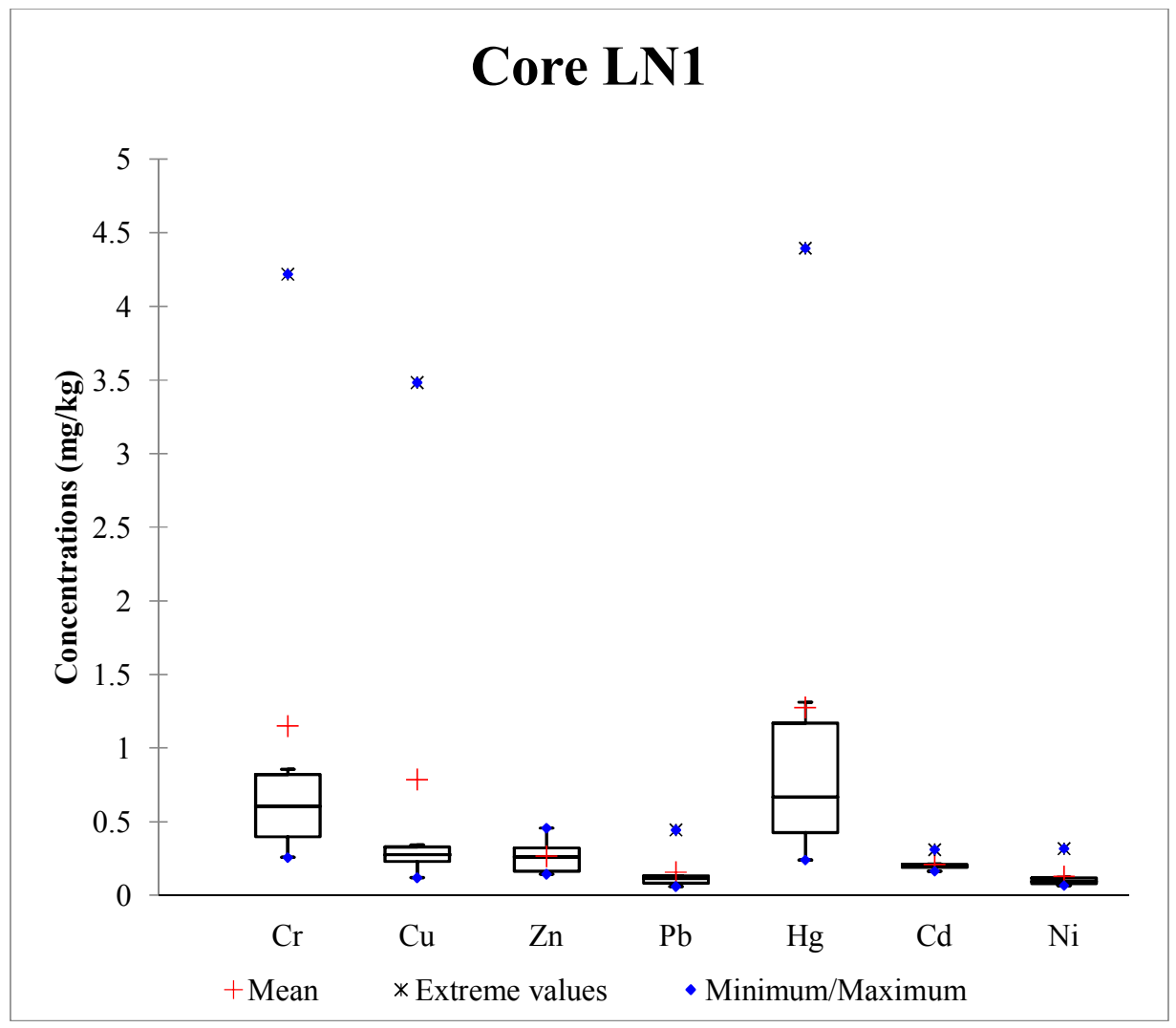




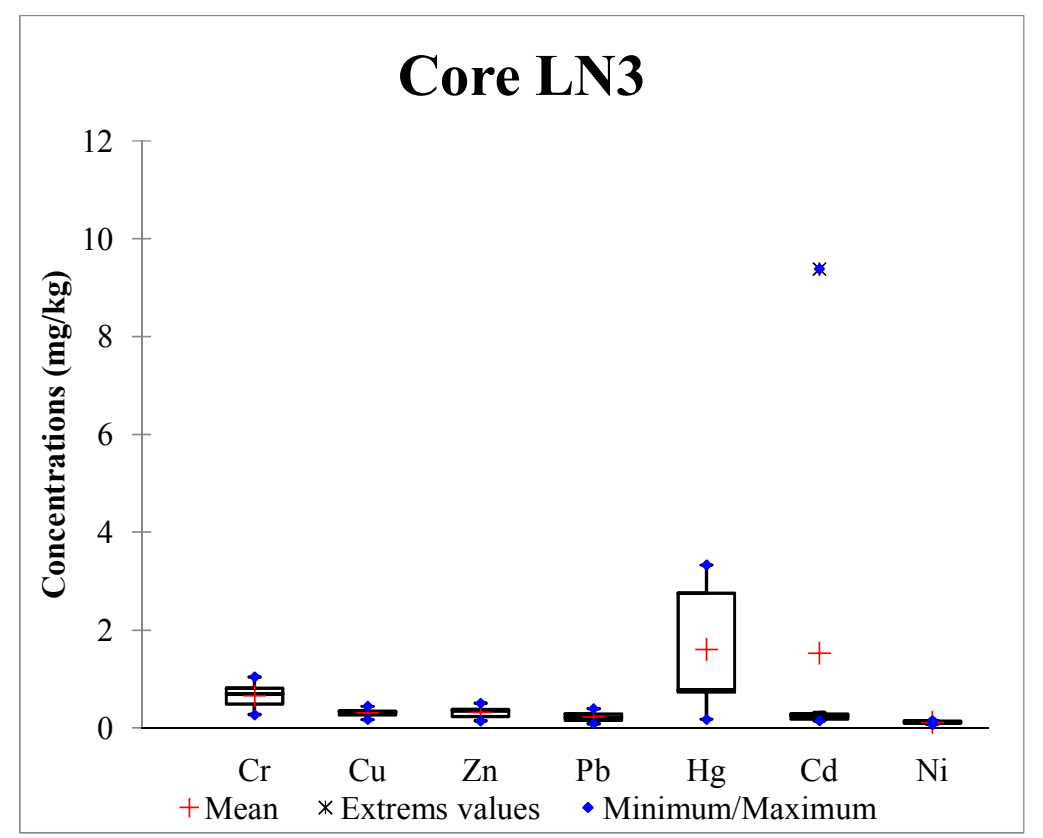

Fig. 3. Concentrations of heavy metals in sediments of the Nkozoa Lake $(\mathrm{mg} / \mathrm{kg})$

\subsubsection{Heavy metals in sediments}

The average concentrations $(\mathrm{mg} / \mathrm{kg})$ of heavy metals vary in the following order: $\mathrm{Hg}(\sim 1.275)$ $>\mathrm{Cr}(\sim 1.150)>\mathrm{Cu}(\sim 0.786)>\mathrm{Zn}(\sim 0.266)>\mathrm{Cd}$ $(\sim 0.210)>\mathrm{Pb}(\sim 0.157)>\mathrm{Ni}(\sim 0.128)$ in the core LN1 located near the entrance of the lake and $\mathrm{Hg}(\sim 1.604)>\mathrm{Cd}(\sim 1.528)>\mathrm{Cr}(\sim 0.655)>$ $\mathrm{Zn}(\sim 0.315)>\mathrm{Cu}(\sim 0.306)>\mathrm{Pb}(\sim 0.225)>\mathrm{Ni}$ $(\sim 0.112)$ in the core LN3 from the centre of the lake (Fig. 3). Mean $\mathrm{Hg}$ concentrations are the highest heavy metal contents in lake sediments of the two cores (Table 2). Average $\mathrm{Cr}$ and $\mathrm{Cu}$ concentrations are higher in the sediments of the core near the lake entrance (LN1). Average Cd concentrations are higher in the sediments of the LN3 core located in the centre of the lake. There was no apparent spatial variability in the mean $\mathrm{Pb}$ and $\mathrm{Ni}$ concentrations, which appear very low in all the samples. Heavy metal concentrations are below the upper continental crust (UCC) and several environmental contamination monitoring parameters, such as threshold effect level (TEL), probable effect level (PEL), and severe effect lever (SEL). The increase in metal content in these sediments implies that a substantial increase in anthropogenic metal loading has occurred in this lake, as suggested by Sondi et al. [36]. This comparison shows that sediments of Lake Nkozoa impact in water quality and aquatic life according to the TEL, PEL and SEL standards.

\subsection{Assessment of Sediments Contamination}

The geo-accumulation index of heavy metals in sediments of Nkozoa Lake showed that the sediments were not polluted (Table 3; Fig. 4), they fall into class 0 . Among the heavy metals, only cadmium shows slight contamination. Thus, $7.7 \%$ Cd show unpolluted sediment from class 0 ; the majority of the $\mathrm{Cd}$ pollution in the sediments of Nkozoa Lake; $69.2 \%$ is from class 1, comprised between 0 and 1 , and representing no to slight contamination; $15.4 \%$ of this element represent moderate contamination (class 2 ), their range values are between 1 and 2; only one sample representing $7.7 \%$ has Igeo $>5$ (class 6 ) and indicates extreme contamination of sediments. This high $\mathrm{Cd}$ enrichment could be explained by anthropogenic activities such as agriculture through the use of chemical inputs, cars and motorcycles washing, effluents from households and finally atmospheric deposits from fuel combustion related to road traffic.

The contamination factor (CF) and pollution load index (PLI) are applied to assess the conservation status of an environment and monitor its condition [37,38]. Table 3 and Fig. 5 show the variation of CF and PLI of sediments in Lake Nkozoa. In general, all elements have low contamination degree in both cores and at all levels except for $\mathrm{Cd}$ which has considerable 
levels of contamination. The highest value of CF was estimated at $7.7 \%$ of the general $\mathrm{Cd}$ contamination rate and it is located at the top of the core from the centre of the lake. The $\mathrm{Cd}$ would therefore have a very high contamination degree (CF > 6) in this part of the core. The previous percentage in these sediments has a significant degree of contamination $(3<\mathrm{CF}<6)$ for this element. In $76.9 \%$ of the sediments of Nkozoa Lake, the Cd ranges between 1 and 3, with a moderate contamination degree. Consequently, the high degree of contamination in $\mathrm{Cd}$ showed that multiple sources contributed significantly to the contaminant loadings in Lake Nkozoa. These sources included semi-industrial inputs, such as palm oil manufacturers, food manufacturers that are located along the stream that feeds the lake, household discharges, agriculture, and livestock. The contamination factor (CF) also indicates that the entire concentration of metals is influenced by anthropogenic inputs, especially highly toxic elements such as $\mathrm{Cd}$, and sometimes $\mathrm{Hg}$ which is enriched at high levels in the sediments.

The PLI values in this study are very low overall. They are below unity except for the top of the core taken around the centre of the lake. These sediments would therefore be considered unpolluted (Table 3). Only a single sample representing less than $8 \%$ of the total collected could be considered polluted. The sediments were slightly contaminated with these metals due to the influence of discrete external sources such as agricultural runoff and other anthropogenic inputs mentioned above.

\subsection{Assessment of Ecological Risk}

Potential ecological risk (PER) represents the sensitivity of the biological community to a given substance and illustrates the risk caused by contamination [39]. The calculated PER indices for an individual element (Er) are shown and the complete PERs (RI) are shown in Table 3 and Figure 6. In Nkozoa Lake, almost all elements had low PERs, except $\mathrm{Cd}$ and $\mathrm{Hg}$. Therefore, the $\mathrm{Er}$ values of the most part $<40$ with the exception of one sampling point in $\mathrm{Cd}$ which presents a high potential ecological risk factor $(\mathrm{Er}$ $=281.52$ ) and some points in $\mathrm{Hg}$ which present at $7.7 \%$, a moderate potential ecological risk factor and at $30.8 \%$, a significant potential ecological risk factor $(80<\mathrm{Er}<160)$, the rest presenting a low potential ecological risk factor. As shown in Table 5, some sediment samples from the studied lake have a high PER. This may be due to the development of the semi-industrial sector and urbanization in the peri-urban area of Nkozoa, and the RI distribution graphs could be useful in identifying the area mostly in need of attention

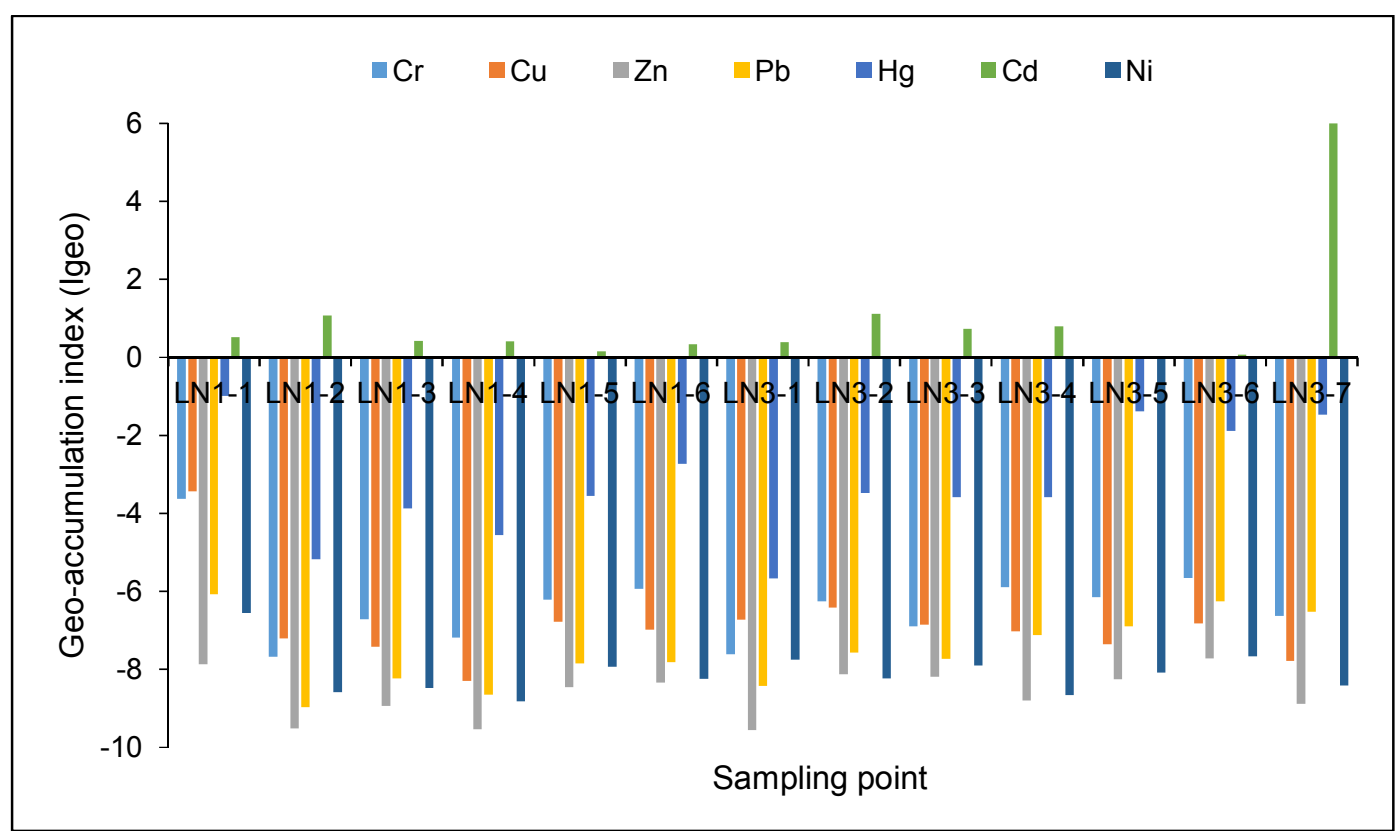

Fig. 4. Geo-accumulation index of selected metals in sediments from Nkozoa Lake 
Table 3. Calculations of geo-accumulation index (I-geo); contamination factor (CF); pollution load index (PLI); potential ecological risk factor (Er) and potential ecological risk index (RI) of metals in Nkozoa Lake sediments

\begin{tabular}{|c|c|c|c|c|c|c|c|c|}
\hline \multicolumn{9}{|c|}{ I-geo } \\
\hline Metals & $\mathrm{Cr}$ & $\mathrm{Cu}$ & $\mathrm{Zn}$ & $\mathrm{Pb}$ & $\mathrm{Hg}$ & Cd & $\mathrm{Ni}$ & \\
\hline LN1-1 & -3.637 & -3.428 & -7.868 & -6.079 & -0.985 & 0.524 & -6.565 & \\
\hline LN1-2 & -7.678 & -7.200 & -9.514 & -8.974 & -5.180 & 1.076 & -8.586 & \\
\hline LN1-3 & -6.712 & -7.413 & -8.936 & -8.232 & -3.876 & 0.425 & -8.478 & \\
\hline LN1-4 & -7.181 & -8.301 & -9.535 & -8.654 & -4.559 & 0.408 & -8.827 & \\
\hline LN1-5 & -6.212 & -6.782 & -8.458 & -7.848 & -3.548 & 0.153 & -7.938 & \\
\hline LN1-6 & -5.939 & -6.986 & -8.346 & -7.822 & -2.730 & 0.336 & -8.237 & \\
\hline LN3-1 & -7.618 & -6.719 & -9.554 & -8.420 & -5.661 & 0.391 & -7.749 & \\
\hline LN3-2 & -6.255 & -6.416 & -8.133 & -7.564 & -3.486 & 1.115 & -8.226 & \\
\hline LN3-3 & -6.898 & -6.850 & -8.186 & -7.729 & -3.583 & 0.736 & -7.894 & \\
\hline LN3-4 & -5.897 & -7.019 & -8.803 & -7.125 & -3.587 & 0.798 & -8.666 & \\
\hline LN3-5 & -6.152 & -7.352 & -8.246 & -6.895 & -1.385 & -0.025 & -8.085 & \\
\hline LN3-6 & -5.655 & -6.822 & -7.721 & -6.257 & -1.879 & 0.065 & -7.670 & \\
\hline LN3-7 & -6.630 & -7.789 & -8.884 & -6.523 & -1.474 & 5.996 & -8.412 & \\
\hline \multicolumn{9}{|c|}{ CF\&PLI } \\
\hline Metals & $\mathrm{Cr}$ & $\mathrm{Cu}$ & $\mathrm{Zn}$ & $\mathrm{Pb}$ & $\mathrm{Hg}$ & Cd & $\mathrm{Ni}$ & PLI \\
\hline LN1-1 & 0.121 & 0.139 & 0.006 & 0.022 & 0.758 & 2.157 & 0.016 & 0.460 \\
\hline LN1-2 & 0.007 & 0.010 & 0.002 & 0.003 & 0.041 & 3.163 & 0.004 & 0.462 \\
\hline LN1-3 & 0.014 & 0.009 & 0.003 & 0.005 & 0.102 & 2.013 & 0.004 & 0.307 \\
\hline LN1-4 & 0.010 & 0.005 & 0.002 & 0.004 & 0.064 & 1.991 & 0.003 & 0.297 \\
\hline LN1-5 & 0.020 & 0.014 & 0.004 & 0.007 & 0.128 & 1.667 & 0.006 & 0.264 \\
\hline LN1-6 & 0.024 & 0.012 & 0.005 & 0.007 & 0.226 & 1.894 & 0.005 & 0.310 \\
\hline LN3-1 & 0.008 & 0.014 & 0.002 & 0.004 & 0.030 & 1.966 & 0.007 & 0.290 \\
\hline LN3-2 & 0.020 & 0.018 & 0.005 & 0.008 & 0.134 & 3.249 & 0.005 & 0.491 \\
\hline LN3-3 & 0.013 & 0.013 & 0.005 & 0.007 & 0.125 & 2.499 & 0.006 & 0.381 \\
\hline LN3-4 & 0.025 & 0.012 & 0.003 & 0.011 & 0.125 & 2.608 & 0.004 & 0.398 \\
\hline LN3-5 & 0.021 & 0.009 & 0.005 & 0.013 & 0.574 & 1.474 & 0.006 & 0.300 \\
\hline LN3-6 & 0.030 & 0.013 & 0.007 & 0.020 & 0.408 & 1.569 & 0.007 & 0.293 \\
\hline LN3-7 & 0.015 & 0.007 & 0.003 & 0.016 & 0.540 & 95.755 & 0.004 & 13.763 \\
\hline \multicolumn{9}{|c|}{ Er\&RI } \\
\hline Metals & $\mathrm{Cr}$ & $\mathrm{Cu}$ & $\mathrm{Zn}$ & $\mathrm{Pb}$ & $\mathrm{Hg}$ & Cd & $\mathrm{Ni}$ & $\mathbf{R I}$ \\
\hline LN1-1 & 21.095 & 17.415 & 0.456 & 2.219 & 175.800 & 6.342 & 1.585 & 224.912 \\
\hline LN1-2 & 1.282 & 1.276 & 0.146 & 0.298 & 9.600 & 9.300 & 0.390 & 22.291 \\
\hline LN1-3 & 2.504 & 1.101 & 0.217 & 0.499 & 23.696 & 5.919 & 0.421 & 34.357 \\
\hline LN1-4 & 1.809 & 0.595 & 0.144 & 0.372 & 14.768 & 5.853 & 0.330 & 23.870 \\
\hline LN1-5 & 3.542 & 1.704 & 0.303 & 0.651 & 29.756 & 4.902 & 0.612 & 41.469 \\
\hline LN1-6 & 4.279 & 1.479 & 0.327 & 0.663 & 52.440 & 5.568 & 0.497 & 65.254 \\
\hline LN3-1 & 1.337 & 1.780 & 0.142 & 0.438 & 6.880 & 5.781 & 0.698 & 17.055 \\
\hline LN3-2 & 3.436 & 2.196 & 0.380 & 0.793 & 31.052 & 9.552 & 0.501 & 47.909 \\
\hline LN3-3 & 2.201 & 1.625 & 0.366 & 0.707 & 29.032 & 7.347 & 0.631 & 41.908 \\
\hline LN3-4 & 4.406 & 1.446 & 0.238 & 1.075 & 28.964 & 7.668 & 0.369 & 44.165 \\
\hline LN3-5 & 3.692 & 1.148 & 0.351 & 1.261 & 133.200 & 4.335 & 0.553 & 144.538 \\
\hline LN3-6 & 5.210 & 1.657 & 0.505 & 1.961 & 94.632 & 4.614 & 0.737 & 109.315 \\
\hline LN3-7 & 2.650 & 0.848 & 0.225 & 1.631 & 125.280 & 281.520 & 0.441 & 412.595 \\
\hline
\end{tabular}




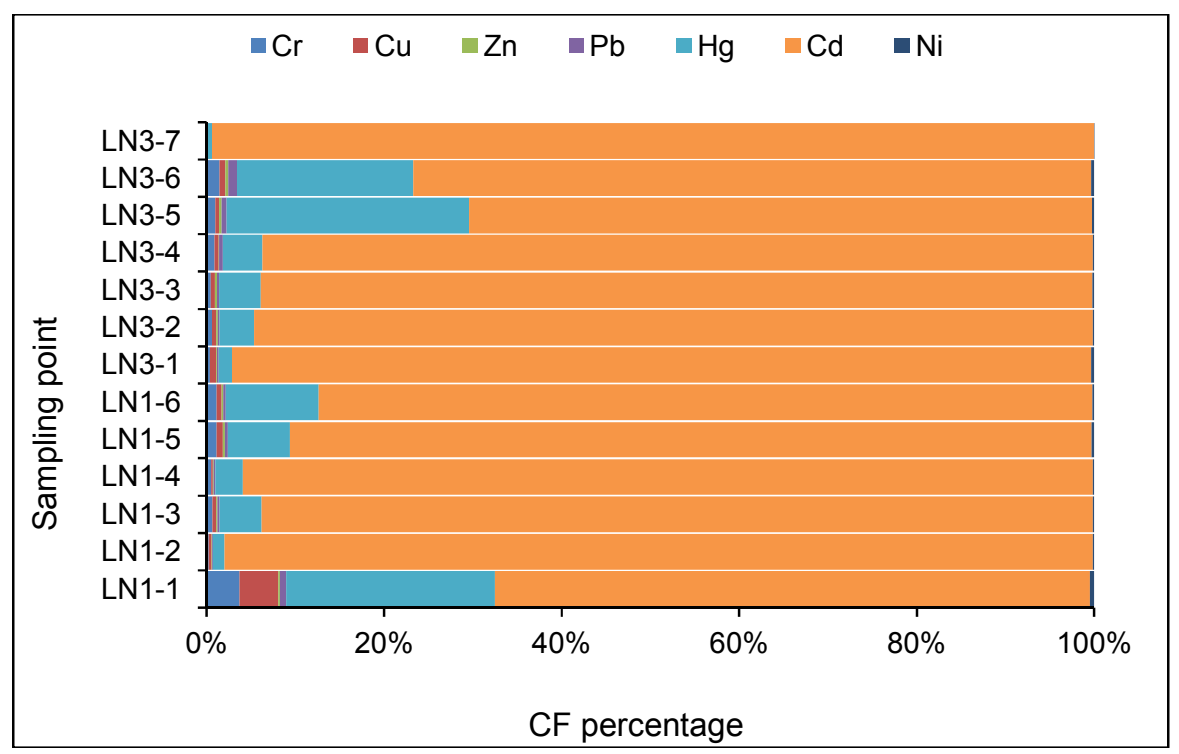

Fig. 5. Contamination factor (CF) and pollution load index (PLI) of heavy metals in the Nkozoa Lake sediments

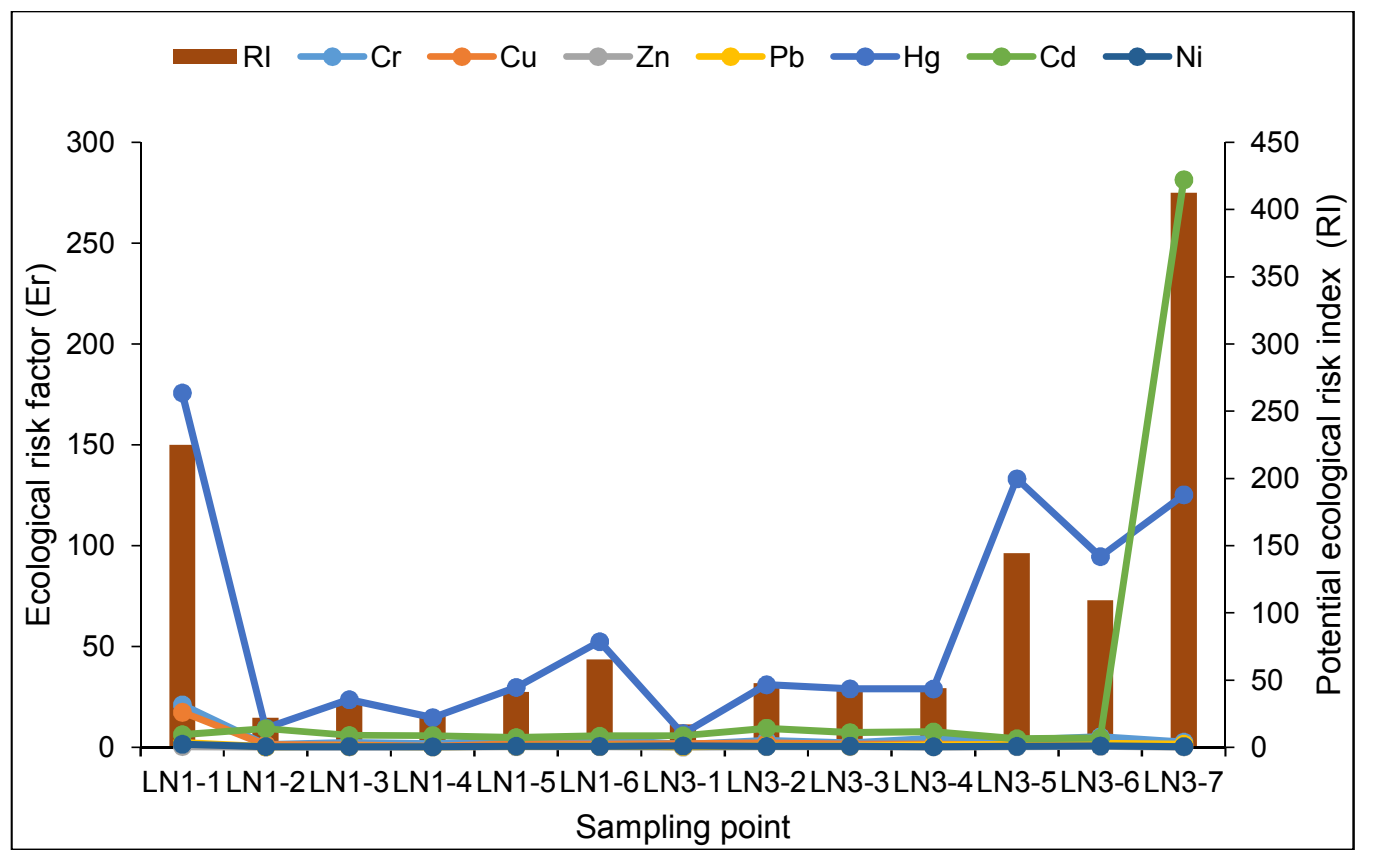

Fig. 6. Ecological risk factor (Er) and ecological risk index (RI) of heavy metals in sediments from the Nkozoa Lake

According to the classification, the risk associated with $\mathrm{Cd}$ and $\mathrm{Hg}$ in the sediments of Nkozoa Lake (RI < 300) shows a low to moderate potential ecological risk index, which corroborates the results of the Igeo, CF, PLI and $\mathrm{Er}$ indices. Contaminants in sediments can enter the food chain, particularly if the contaminants are in bioavailable forms. Cadmium and $\mathrm{Hg}$ can accumulate in relatively large amounts in plants with no apparent effects, which could cause human health problems [22,40]. It is therefore important to continue to carefully monitor heavy metal contaminants, particularly $\mathrm{Cd}$, in lake sediments in Nkozoa. 


\subsection{Statistical Analysis}

Variable relationships can provide information on the sources of heavy metals and chemical parameters [41]; therefore, Pearson's correlation coefficients for heavy metals and chemical parameters were analyzed (Table 4). The Pearson's correlation coefficient analysis amongst the chemical parameters of water and heavy metals for water and sediment samples was performed and presented in Tables 1 and 2 . In water samples (Table 4), pH showed a perfect positive correlation with $\mathrm{EC}, \mathrm{Cr}$ and each other $(r$ $=1.00)$. Similarly, TDS, Cu showed a perfect positive correlation with $\mathrm{Hg}(r \sim 1.00)$, suggesting a common source of $\mathrm{Cu}$ and $\mathrm{Hg}$. TDS and $\mathrm{pH}$ showed significant positive correlations with all metals except $\mathrm{Pb}$ and $\mathrm{Ni}$. Likewise, a close relationship was also observed in water samples between $\mathrm{Hg}$ and all metals except $\mathrm{Pb}$ and $\mathrm{Ni}$, whereas a perfect negative correlation $(r=-1)$ was observed between $\mathrm{Pb}$ and $\mathrm{Cd}$ and between
TDS and $\mathrm{Ni}$. A significant to strong negative correlation ( $r=-0.69$ to -0.98 ) was also found between $\mathrm{Ni}$ and other parameters and some metals (e.g., $\mathrm{Cr}, \mathrm{Cu}, \mathrm{Hg}$ and $\mathrm{Cd}$ ). Correlation coefficients $(r)$ between the physicochemical properties and different heavy metal concentrations in water samples (Table 4) suggested that the concentrations of metals are not linked to $\mathrm{Ni}$ and $\mathrm{Pb}$ contamination, but can be very close to $\mathrm{Cr}, \mathrm{Cu}$ and $\mathrm{Hg}$ productions.

In sediment samples (Table 5), significant to strong positive correlations $(p>0.05)$ between all elements with each other except $\mathrm{Cd}(r=0.46$ to 0.97) were observed. The matrix data for the studied sediments revealed that Cd was lowly positively and negatively correlated with other parameters (ranging from $r=-0.11$ to 0.36 ), suggesting a different source of these metals and that Cd contamination in sediments is not directly linked to other metals.

Table 4. Pearson correlation matrix of heavy metals and water quality parameters of water samples

\begin{tabular}{lllllllllll}
\hline Variables & $\mathbf{p H}$ & TDS & $\mathbf{E C}$ & $\mathbf{C r}$ & $\mathbf{C u}$ & $\mathbf{Z n}$ & $\mathbf{P b}$ & $\mathbf{H g}$ & $\mathbf{C d}$ & $\mathbf{N i}$ \\
\hline $\mathrm{pH}$ & 1 & & & & & & & & & \\
$\mathrm{TDS}$ & 0.96 & 1 & & & & & & & & \\
$\mathrm{EC}$ & 1.00 & 0.97 & 1 & & & & & & & \\
$\mathrm{Cr}$ & 1.00 & 0.96 & 1.00 & 1 & & & & & & \\
$\mathrm{Cu}$ & 0.91 & 0.99 & 0.92 & 0.92 & 1 & & & & & \\
$\mathrm{Zn}$ & 0.47 & 0.20 & 0.45 & 0.45 & 0.06 & 1 & & & & \\
$\mathrm{~Pb}$ & -0.47 & -0.70 & -0.49 & -0.49 & -0.80 & 0.56 & 1 & & & \\
$\mathrm{Hg}$ & 0.92 & 0.99 & 0.93 & 0.93 & 1.00 & 0.09 & -0.77 & 1 & & \\
$\mathrm{Cd}$ & 0.46 & 0.69 & 0.48 & 0.47 & 0.79 & -0.57 & -1.00 & 0.76 & 1 & \\
$\mathrm{Ni}$ & -0.98 & -1.00 & -0.98 & -0.98 & -0.97 & -0.28 & 0.64 & -0.98 & -0.63 & 1 \\
\hline \multicolumn{7}{c}{ Values in bold are different from 0 at significance level alpha $=0.05$} & &
\end{tabular}

Table 5. Pearson correlation matrix of heavy metals of sediment samples

\begin{tabular}{llllllll}
\hline Variables & $\mathbf{C r}$ & $\mathbf{C u}$ & $\mathbf{Z n}$ & $\mathbf{P b}$ & $\mathbf{H g}$ & $\mathbf{C d}$ & $\mathbf{N i}$ \\
\hline $\mathrm{Cr}$ & 1 & & & & & & \\
$\mathrm{Cu}$ & 0.97 & 1 & & & & & \\
$\mathrm{Zn}$ & 0.57 & 0.46 & 1 & & & & \\
$\mathrm{~Pb}$ & 0.71 & 0.60 & 0.71 & 1 & & & \\
$\mathrm{Hg}$ & 0.71 & 0.62 & 0.60 & 0.90 & 1 & & \\
$\mathrm{Cd}$ & -0.11 & -0.12 & -0.17 & 0.31 & 0.36 & 1 & \\
$\mathrm{Ni}$ & 0.92 & 0.94 & 0.59 & 0.66 & 0.65 & -0.15 & 1 \\
\hline \multicolumn{7}{c}{ Values in bold are different from 0 at significance level alpha $=0.05$} &
\end{tabular}



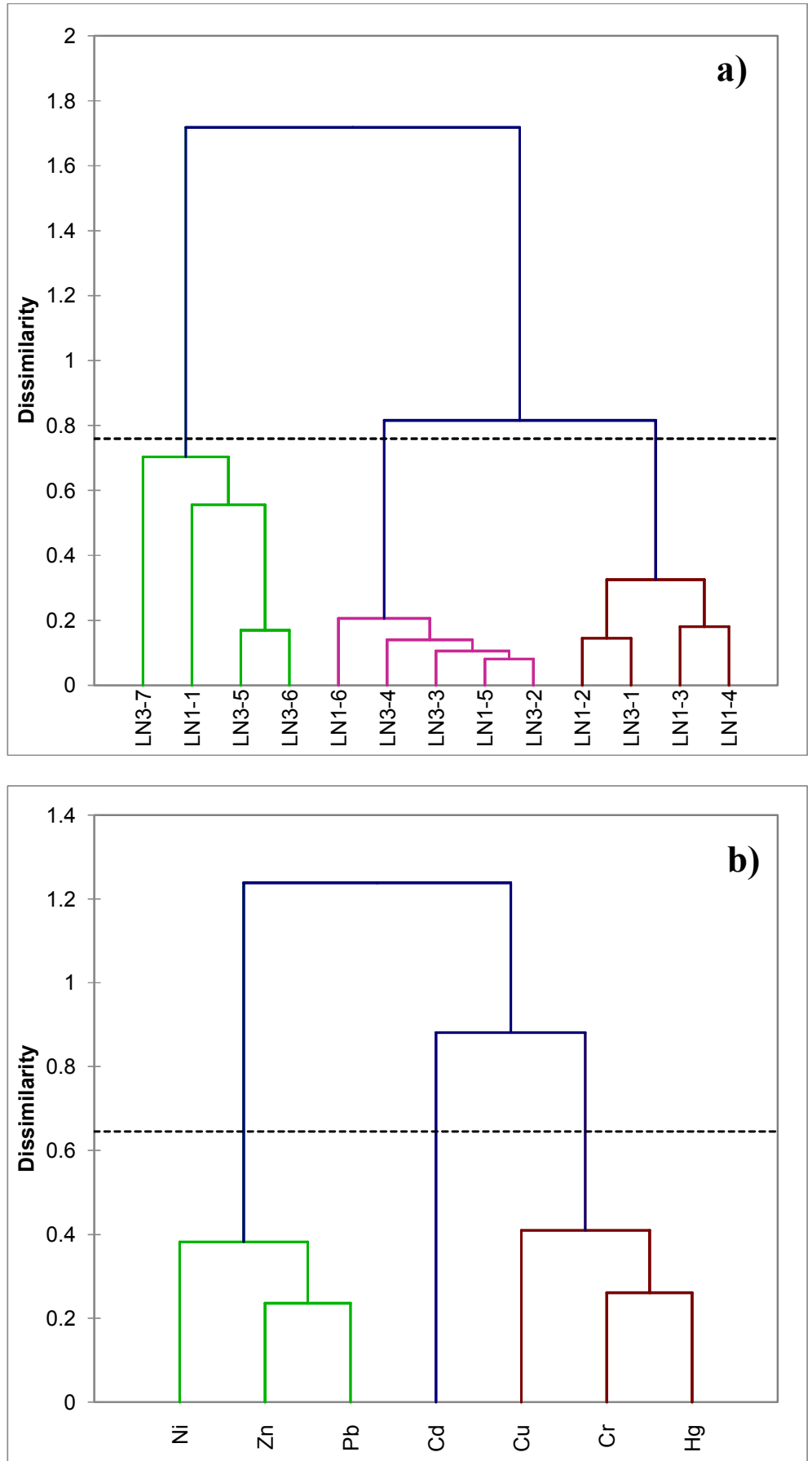

Fig. 7. Dendrogram clustering: a) sediment sampling locations and b) analyzed parameters in sediment samples from the Nkozoa Lake

A cluster analysis was performed on heavy metals of sediment from Nkozoa Lake using between-groups linkage method with Pearson correlation [42]. Cluster analysis was used to group the similar sampling sites (spatial variability) and to identify source of heavy metal contamination [43,44]. Hierarchical agglomerative was performed on the normalized data set using Ward's method with Euclidean distances as a measure of similarity. In order to 
identify relationships between the analyzed parameters and their possible sources, cluster analyses resulted in two dendrograms (Fig. 7) where the thirteen samples from two cores from Lake Nkozoa were grouped into two statistically significant clusters. In the first dendogram (Fig. 7a) focussed on spacial similarity, two statistically significant clusters at (Dlink/Dmax) > 0.76 are grouped. Cluster 1 consists of four samples (LN1-1, LN3-7, LN3-6 and LN3-5) principally samples from the top of the center of the cores, cluster 2 is made up of the samples from the middle of the cores (LN1-6, LN1-5, LN32, LN3-3 and LN3-4) and cluster 3 consists of four basal samples especially from the core located at the entrance of the lake (LN1-4, LN12, LN3-3 and LN3-1). The cluster classifications vary with significance level because the samples in these clusters had similar characteristic features and anthropogenic/natural background source types. Cluster 1 corresponds to the highest contaminated samples and cluster 3 corresponds to the lowest contaminated samples. Similarly, cluster analysis was performed to identify the relationships among the analyzed parameters and their possible sources $[45,46]$. Cluster analysis rendered a dendrogram (Fig. 7b) where all seven parameters were grouped into three statistically significant clusters at $($ Dlink/Dmax $)>0.65$. Cluster 1 includes $\mathrm{Ni}, \mathrm{Pb}$ and $\mathrm{Zn}$, which in the previous section were identified as non-pollutants, cluster 2 contains $\mathrm{Cd}$, the most contaminant elements from the studied metals. This element was lowly positively and negatively correlated with other parameters (Table 5). Cadmium mainly derives from anthropogenic sources (agriculture, washing of cars and motorcycles, effluents from households and road traffic). Cluster 3 , which contains $\mathrm{Cu}, \mathrm{Cr}$ and $\mathrm{Hg}$, is derived from lithogenic sources, also confirmed by their strong positive correlations (Table 5) and their small variabilities along the cores (Table 2).

\section{CONCLUSION}

The purpose of this study was to assess levels of physico-chemical parameters of water (TDS, EC and $\mathrm{pH}$ ) and seven metals ( $\mathrm{Cr}, \mathrm{Cu}, \mathrm{Zn}, \mathrm{Pb}, \mathrm{Hg}$, $\mathrm{Cd}$ and $\mathrm{Ni}$ ) in both surface water and sediment samples from the Nkozoa Lake. The following conclusions can be drawn:

1- The results obtained from physicochemical parameters of water show that the $\mathrm{pH}, \mathrm{EC}$ and TDS measured during the study period are below the recommendations of the WHO. The acid values of the water of this lake are lower than those of a healthy lake.

2- Mean concentrations of the seven heavy metals in water samples are lower than the WHO (2017) recommended guideline for drinking water except $\mathrm{Zn}$. The main source of heavy metals in the water appears to be the discharge of waste streams from various semi-industrial processes, agriculture and farming carried out in the watershed of Lake Nkozoa.

3- The average heavy metal concentrations in sediments are lower than the TEL, PEL, SEL and UCC with exception of Cd. The sediment samples show a low degree of contamination by heavy metals and low PER level, except for $\mathrm{Cd}$ and $\mathrm{Hg}$ sometimes which has high contamination degree and moderate PER. These contaminants can accumulate in relatively large amounts in plants with no apparent effects, which could cause human health problems.

4- Matrix correlation showed that some parameters like $\mathrm{pH}, \mathrm{EC}$ and $\mathrm{Cr}$ on the one hand and, TDS, $\mathrm{Cu}$ and $\mathrm{Hg}$ in water on the second hand, have common sources. The statistical analysis also shows that the concentrations of metals were not linked to $\mathrm{Ni}$ and $\mathrm{Pb}$ contamination, but can be very close to $\mathrm{Cr}, \mathrm{Cu}$ and $\mathrm{Hg}$ productions. The matrix data for studied sediments revealed that $\mathrm{Cd}$ contamination could not be directly linked to other metals.

5- The cluster classifications for sediment samples varied with significance level and are group into similar characteristic features and anthropogenic/natural background source types from contaminated to uncontaminated samples. It also shows that $\mathrm{Cd}$ is the most contaminant element from the studied metals and derived from anthropogenic sources. However, $\mathrm{Cu}, \mathrm{Cr}$ and $\mathrm{Hg}$ are derived from lithogenic sources while the other elements appear as natural.

6- Due legal measures such as the control of wastes should be taken to reduce the anthropogenic discharges in the Nkozoa Lake; the constant collection of household waste and other activities by the existing sanitation company or the creation of a new structure to deal with it; otherwise, future high levels of contamination will greatly influence the population and will invite socio-economic disaster. Moreover, 
a regular monitoring program of the heavy metals is recommended to protect this lake and also reduce environmental risks.

\section{ACKNOWLEDGEMENTS}

This research was partly supported by the Department of Earth Sciences, Faculty of Sciences, University of Yaoundé I, through an on-going internal project.

\section{COMPETING INTERESTS}

Authors have declared that no competing interests exist.

\section{REFERENCES}

1. $\mathrm{Yu} \mathrm{KC}$, Tsai LJ, Chen SH, Ho ST. Chemical binding of heavy metals in anoxic river sediments. Water Research. 2001;35(17):4086-4094.

2. Tehna N, Sababa E, Ekoa Bessa AZ, Etame J. Mine waste and heavy metal pollution in Betare-oya mining area (eastern Cameroon). Environmental and Earth Sciences Research Journal. 2019;6(4):167-176.

3. Zhang C, Yi X, Chen C, Tian D, Liu H, Xie $L$, Ying GG. Contamination of neonicotinoid insecticides in soil-watersediment systems of the urban and rural areas in a rapidly developing region: Guangzhou, South China. Environment International. 2020;139:105719.

4. Ekoa Bessa AZ, Armstrong-Altrin JS, Fuh GC, Betsi TB, Kelepile T, Ndjigui P-D. Mineralogy and geochemistry of the Ngaoundaba Crater Lake sediments, northern Cameroon: Implications for provenance and trace metals status. Acta Geochimica. 2021;1-21.

5. Rahman MS, Islam MR. Adsorption of Cd (II) ions fromsynthetic waste water using maple sawdust. Energy Sour Part A: Recovery Util Environ Eff. 2010;32(3):222231.

6. Mandeng EPB, Bidjeck LMB, Ekoa Bessa AZ, Ntomb YD, Wadjou JW, Doumo EPE, Bitom LD. Contamination and risk assessment of heavy metals, and uranium of sediments in two watersheds in AbieteToko gold district, Southern Cameroon. 2019; Heliyon 5:e02591.

7. Mamat A, Zhang Z, Mamat Z, Zhang F, Yinguang $C$. Pollution assessment and health risk evaluation of eight (metalloid) heavy metals in farmland soil of 146 cities in China. Environmental Geochemistry and Health. 2020;42(11):P3949-3963.

8. Ekoa Bessa AZ, Ngueutchoua G, Janpou AK, El Amier YA, Nguetnga OANNM, Kayou URK, Armstrong Altrin JS. Heavy metal contamination and its ecological risks in the beach sediments along the Atlantic Ocean (Limbe coastal fringes, Cameroon). Earth Systems and Environment. 2020;1-12.

9. Ahamad MI, Song J, Sun $H$, Wang $X$, Mehmood MS, Sajid M, Su P, Khan AJ. Contamination level, ecological risk, and source identification of heavy metals in the hyporheic zone of the Weihe River, China. International journal of environmental research and public health. 2020;17(3):1070.

10. Filgueiras AV, Lavilla I, Bendicho C. Evaluation of distribution, mobility and binding behaviour of heavy metals in surficial sediments of Louro River (Galicia, Spain) using chemo metric analysis: A case study. Science of the Total Environment. 2004;330(1-3):115-129.

11. Joksimovic D, Tomic I, Stankovic AR, Jovic M, Stankovic S. Trace metal concentrations in mediterranean blue mussel and surface sediments and evaluation of the mussels quality and possible risks of high human consumption. Food Chemistry. 2011;127(2):632-637.

12. Rahman HR, Priyank $P$, Lavanya $T$, Srilakshmi NS, Kumar PRKR. A review on ethnobotany, phytochemisrty and pharmacology of Citrullus lanatus $\mathrm{L}$. International Research Journal of Pharmaceutical and Applied Sciences. 2013;3(2):77-81.

13. Varol M, Gökot B, Bekleyen A, Şen B. Water quality assessment and apportionment of pollution sources of Tigris River (Turkey) using multivariate statistical techniques - A case study. River Research and Applications; 2013.

DOI:10.1002/ rra.1533.

14. Kükrer S, Mutlu E. Assessment of surface water quality using water quality index and multivariate statistical analyses in Saraydüzü Dam Lake, Turkey. Environmental monitoring and assessment. 2019;191(2):71.

15. Phiri O, Mumba P, Moyo BHZ, Kadewa W. Assessment of the impact of industrial effluents on water quality of receiving rivers in urban areas of Malawi. 
International Environmental Science and Technology. 2005;2(3):237-244.

16. Ekoa Bessa AZ, Ngueutchoua G, Ndjigui P-D. Mineralogy and geochemistry of sediments from Simbock Lake, Yaoundé area (southern Cameroon): Provenance and environmental implications. Arabian Journal of Geosciences. 2018a;11(22):710.

17. Wang $X$, Li C, Yuan $X$, Yang $S$. Contamination level, distribution characteristics, and ecotoxicity of tetrabromobisphenol a in water and sediment from Weihe River Basin, China. International Journal of Environmental Research and Public Health. 2020;17(11):3750.

18. Noa Tang SD, Messina TR, Onana VL, Ekoa Bessa AZ, Ndjigui P-D. Risk assessment of trace metals in Mefou River sediments, West-Africa. Heliyon. accepted; 2021.

19. Kannel PR, Lee S, Lee YS, Kanel SR, Khan SP. Application of water quality indices and dissolved oxygen as indicators for river water classification and urban impact assessment. Environmental Monitoring and Assessment. 2007;132(13):93-110.

20. Morroni L, d'Errico G, Sacchi M, Molisso F, Armiento G, Chiavarini S, Aliberti F. Integrated characterization and risk management of marine sediments: the case study of the industrialized Bagnoli area (Naples, Italy). Marine Environmental Research. 2020;104984.

21. Yonta-Ngoune C, Nkoumbou C, Barbey $P$, Le Breton N, Montel JM, Villiéras F. Geological context of the Boumnyebel talcschists (Cameroun): Inferences on the Pan-African Belt of Central Africa. Comptes Rendus Géoscience. 2010;342(2):108-115.

22. Ekoa Bessa AZ, El-Amier YA, Doumo EPE, Ngueutchoua G. Assessment of sediments pollution by trace metals in the Moloundou swamp, southeast Cameroon. Annual Research \& Review in Biology. 2018b;1-13.

23. N'nanga A, Simon III N, Ngueutchoua G. The late pleistocene-holocene paleoclimate reconstruction in the adamawa plateau (Central Cameroon) inferred from the geochemistry and mineralogy of the Lake Fonjak sediments. Journal of African Earth Science. 2019;150:23-36.
24. Ndam Ngoupayou JR, Kpoumie A, Boeglin JL, Liénou G, Nfocgo AK, Ekodeck GE. Transports solides et érosion mécanique dans un écosystème tropical d'Afrique : Exemple du bassin versant de la Sanaga au Sud-Cameroun. In Proceedings of the JSIRAUF (1res Journées Scientifiques Inter-Réseaux de l'AUF, Hanoi, Vietnam). 2007;6-9.

25. Mimba ME, Ohba T, Fils SCN, Wirmvem MJ, Numanami N, Aka FT. Seasonal hydrological inputs of major ions and trace metal composition in streams draining the mineralized lom basin, East Cameroon: Basis for environmental studies. Earth Systems and Environment. 2017;1(2):22.

26. Muller G. Index of geoaccumulation in sediments of the Rhine River. Geological journal. 1969;2:108-118.

27. Taylor SR, McLennan SM. The geochemical evaluation of the continental crust. Review of Geophysic. 1995;33:241265.

28. Hakanson L. An ecological risk index for aquatic pollution control. A sedimentological approach. Water Research. 1980;14(8):975-1001.

29. Tomlinson DL, Wilson JG, Harris CR, Jeffrey DW. Problems in the assessment of heavy-metal levels in estuaries and the formation of a pollution index. Helgoländer Meeresuntersuchungen. 1980;33(14):566-575.

30. Zhu X, Hill RA, Nishiyama A. NG2 cells generate oligodendrocytes and gray matter astrocytes in the spinal cord. Neuron glia biology. 2008;4 (1):19.

31. Oumar B, Ekengele NL, Balla OAD. Évaluation du niveau de pollution par les métaux lourds des lacs Bini et Dang, Région de l'Adamaoua, Cameroun. Afrique Science: Revue Internationale des Sciences et Technologie. 2014;10(2).

32. Kwon JC, Léopold EN, Jung $M C$, Emmanuel EG, Israël ML, Kim KH. Impact assessment of heavy metal pollution in the municipal lake water, Yaounde, Cameroon. Geosciences Journal. 2012;16(2):193-202.

33. World Health Organization. Guidelines for drinking-water quality. Fourth edition Incorporating the first addendum. 2017;1631.

34. Ikem A, Egiebor NO, Nyavor K. Trace elements in water, fish and sediment from Tuskegee Lake, Southeastern USA. Water, Air and Soil Pollution. 2003;149(14):51-75. 
35. Kaki R, Elligsen M, Walker S, Simor A, Palmay L, Daneman N. Impact of antimicrobial stewardship in critical care: A systematic review. Journal of antimicrobial chemotherapy. 2011;66(6):1223-1230.

36. Sondi I, Lojen S, Juracic M, Prohic E. Mechanism sofland-seainteractions- the distribution of metals and sedimentary organic matter in sediments of a riverdominated Mediterranean karstic estuary. Estuarine, Coastal and Shelf Science. 2008;80:12-20.

37. Davis ME, Zuckerman JE, Choi CHJ, Seligson D, Tolcher A, Alabi CA, Ribas A. Evidence of RNAi in humans from systemically administered siRNA via targeted nanoparticles. Nature. 2010;464(7291):1067-1070.

38. Casado-Martinez MC, Forja JM, DelValls TA. A multivariate assessment of sediment contamination in dredged materials from Spanish ports. Journal of Hazardous Materials. 2009;163:1353-1359.

39. Suresh G, Sutharsan P, Ramasamy V, Venkatachalapathy $R$. Assessment of spatial distribution and potential ecological risk of the heavy metals in relation to granulometric contents of Veeranam lake sediments, India. Ecotoxicology and Environmental Safety. 2012;84:117-124.

40. Zhao LYL, Schulin R, Nowack B. The effects of plants on the mobilization of $\mathrm{Cu}$ and $\mathrm{Zn}$ in soil columns. Environmental Science and Technology. 2007;41:27702775.
41. Dragovic S, Mihailivic N, Gajic B. Heavy metals in soils: Distribution, relationship with soil characteristics and radionuclides and multivariate assessment of contamination sources. Chemosphere. 2008;72: 491-495

42. Le Maitre RW. Numerical Petrology. Elsevier, Amsterdam; 1982.

43. Simeonov V, Massart DL, Andreev G, Tsakovski S. Assessment of metal pollution based on multivariate statistical modeling of hot spot sediments from the Black Sea. Chemosphere. 2000;41:14111417.

44. Sundaray SK, Nayak BB, Lin S, Bhatta D. Geochemical speciation and risk assessment of heavy metals in the river estuarine sediments-a case study: Mahanadi basin, India. Journal of Hazardous Materials. 2011;186:18371846.

45. Li J, He M, Han W, Gu Y. Analysis and assessment on heavy metal sources in the coastal soils developed from alluvial deposits using multivariate statistical methods. Journal of Hazardous Materials. 2009;164:976-981.

46. Chung CY, Chen JJ, Lee CG, Chiu CY, Lai WL, Liao SW. Integrated estuary management for diffused sediment pollution in Dapeng Bay and neighboring rivers (Taiwan). Environmental Monitoring and Assessment. 2011;173:499-517.

(c) 2021 Noa Tang et al.; This is an Open Access article distributed under the terms of the Creative Commons Attribution License (http://creativecommons.org/licenses/by/4.0), which permits unrestricted use, distribution, and reproduction in any medium, provided the original work is properly cited.

Peer-review history:

The peer review history for this paper can be accessed here: http://www.sdiarticle4.com/review-history/67858 